\title{
Canvas Business Model Marketer Village, Tunjungmuli Purbalingga
}

\author{
Hermin Endratno ${ }^{1}$, Selamet Eko Budi Santoso ${ }^{2}$ \\ \{herminendratno@ump.ac.id, Budi.imm@gmail.com\} \\ A Doctoral Student of UNSOED Purwokerto ; A Lecturer of FEB Universitas Muhammadiyah \\ Purwokerto ${ }^{1}$, \\ Universitas Muhammadiyah Purwokerto, Jln.KH.Akhmad Dahlan Purwokerto ${ }^{2}$
}

\begin{abstract}
Mapping the business model with the Business Model Canvas approach carried out on the nine-block elements, including customer segments, value propositions, channels, customer relationships, revenue streams, key activities, key resources, key partnerships, and cost structures, in general, is said to be quite good. Some existing business models can fulfill the nine-building block elements of the Business Model Canvas. Based on the evaluation results using SWOT analysis to the nine-building block elements on this Business Model regarding strengths and weaknesses, opportunities, and threats owned by Marketer Village, it generates a strategy conclusion as the recommendation for Marketer Village management so that it can improve the existing business models. Of the nine-building block elements in the existing Business Model Canvas, researchers recommend additions aimed at several building blocks, namely Value Propositions, Revenue Streams, Key Resources, Key Activities, Key Partnerships, and Cost Structure.
\end{abstract}

Keywords: canvas business model, marketer village

\section{Introduction}

One effort to advance and improve the local economy is to encourage village-level development based on local wisdom, resource potential, and uniqueness. Innovative villages can be established in the villages that can utilize their resources in different and unique ways. Based on data from Cooperatives and Small and Medium Enterprises (SMEs), the number of Indonesian entrepreneurs only reached 3.1 percent of the 250 million population of Indonesia. Of these, only a small number of SMEs use the online platform as a marketing tool. "There are still a small number of e-SMEs. There is no data on that (under 10 percent from 3.1 percent) (Deputy for Infrastructure, Creative Economy Agency (BeKraf). If the progress is based on various sources, the growth of e-commerce in Indonesia is still at 1-2 percent. The growth rate of e-commerce is expected to change the mindset that this country is tremendously potential to be increased because it has achieved about 2 percent. The benefits of selling through the internet media (E-commerce) are its flexibility in terms of days and places, all days are just the same, and all transactions can be done anytime and anywhere.

The development of information technology in the context of society occurs in almost all aspects of daily life. There has been a technological convergence that has reduced the people's traditional habits and has been replaced by new habits based on information technology. Communication patterns develop through technology media such as cellular phones and buying 
and selling transactions develop online [1]. At present, the village has begun to apply information technology-based villages or referred to as smart villages. Although there is not yet an understanding of the concept of a smart village, in general, a village can be said to be a smart village if the village innovatively uses information technology to achieve an improved quality of life, efficiency and competitiveness in economic, social and environmental aspects [2]. In practice, this understanding is interpreted differently. The implication is that each village declares it as a smart village without being supported by the same and adequate size elements of the smart village.

Tunjungmuli Village, Karang Poncol Subdistrict, is one of the marketer villages in Purbalingga Regency. To the researchers' knowledge, so far, there has been no empirical research aimed at analyzing the factors that influence citizens to work in the creative economy through e-commerce because the phenomenon is still new. Therefore, this study makes a practical contribution, especially in developing models that can later be adopted or adapted according to village characteristics. At present, no guidance scheme can be used as an indicator in determining marketer villages. This condition is an obstacle in its operation. By looking at these conditions, this research becomes essential to do for some reasons such as helping local governments determine which villages will be developed, providing instruments that can be used in determining which villages will be developed into the next marketer villages. Besides, there needs to be a model canvas business to enrich the realm of business scholarship.

Tabel 1. Previous Research

\begin{tabular}{ll}
\hline No & Researcher, Year \\
\hline 1 & {$[3]$ Chandra and } \\
& Kempa (2016)
\end{tabular}

Research result

In customer segments, Sifu Pudding Cream is included in the niche market type. In the value propositions element, company brand image can be added as homemade pudding and halal. On the channel element, it is known that Sifu Pudding Cream only applies channels through the telephone system and online ordering. The customer relationship elements in Sifu Pudding Cream can be added automated services, self services where customers can provide input, criticism and suggestions directly to employees or owners via the website. In the key resources element, it is known that Sifu Pudding Cream's resources consist of physical, human, intellectual and financial resources. The main resource focused by Sifu Pudding Cream in the future is the addition of physical assets in the form of physical stores and generators. In the key activities element, the activities added are inventory control and maintaining product consistency. Within the keypartnerships element, new food couriers and suppliers can be added for new Sifu Pudding Cream products. The revenue streams element Sifu Pudding Cream is known that income is sourced from one income stream and efforts can be added to increase income streams from class procurement making pudding for children can provide income from monthly subscription fees and asset sales from the sale of materials used by students. The cost structure element is included in value driven with expenses divided into fixed costs and variable costs. 
2 [4]Yashinta (2017)

3 [5]Alvino (2017)
The results show that Limakilo's customer segment is a segmented market. The value proposition is that the product price is cheaper than traditional markets in Jakarta due to supply chain cutoffs. Channels use indirect and direct channels. Customer relations is a personal assistant to help and serve customers, self-service during the ordering process. The revenue stream is obtained from sales of shallots, garlic, chilies, tomatoes, potatoes and rice, as well as investment. Main Resources consist of platforms and trello, people, offices, laptops, agricultural tools, and finance. Main activities include activities with assisted farmers and suppliers, online and offline business activities. Main partnership suitability with assisted farmers, Indimira and KUDO, coopetition with Kanigoro, and suppliers. Fee structure in fully micro-financed farmers and enterprises. This business model results in efficiency but still needs to provide an increase in their business activities as well

The fried chicken business has become popular in recent years. Chicken Kashibu is $a$ fried chicken franchise that was founded in 2011 in the city of Bekasi. By selling fast food dishes with processed chicken meat and many competitors that emerged, Kashibu Chicken had to pay attention to taste in order to compete. By prioritizing the taste, it is clear that the Kashibu Chicken must maintain the quality of the chicken, over time the problem that often occurs is that the seasoned chicken rots quickly. Chicken Kashibu wanted to make the right business model to see if there needs to be a change from the current business model. This study aims to map the Kashibu Chicken business process using the nine blocks of the canvas business model from Osterwalder and Pigneur and to design a recommendation canvas business model that can solve existing problems, and make a SWOT analysis to see where the strengths, weaknesses, opportunities, and threats of the business are. Kashibu Chicken.

This research uses forecasting methods to solve existing problems, and primary data that can be obtained directly and interviews. As well as collecting secondary data through internet access for research data. The results of this study indicate that the business model needs improvement in the key activity blocks by adding demand forecasting activities.

\section{Literatrie Review}


The Canvas Business Model is a business strategy management that allows us to describe, design and then reduce several aspects of the business into a complete business strategy.[6] The following are the elements of $\mathrm{BMC}$ and their explanations:

\section{a) Customer Segment}

Customer segment describes groups of people or organizations that the business company wants to reach and serve. There are various types of customer segments, namely mass market, niche market, segmented, diversified, multi-sided platforms.

\section{b) Value Propositions}

The value propositions building block describes a set of products or services that create value aimed at a specific customer segment. This value can be either quantitative (eg price, speed of service) or qualitative (eg design, customer experience). Various value propositions are newness, performance, customization, getting the job done, design, brand / status, price, cost reduction, risk reduction, accessibility, convenience / usability.

\section{c) Channels}

Channels are divided into direct and indirect, as well as divided into channel owned by themselves and channels owned by partners. Own direct channels for example in-house sales and websites. Meanwhile, indirect channels are owned, for example retail. Partner owned channels are indirect and allow companies to expand their reach and benefit from partner strength. For example wholesale, retail, or partner-owned web sites. The channel consists of the awareness, evaluation, purchase, delivery, and after-sales phases.

\section{d) Customer Relationship}

Customer relationship describes the various types of relationships that companies create with specific customer segments. Customer relationships can be influenced by various motives, namely customer acquisition, customer retention, boosting sales (upselling). Customer relationships can be categorized into personal assistance, dedicated personal assistance, selfservice, automated services, co-creation, and communitites.

\section{e) Revenue Streams}

Revenue streams describe the cash flow that the company receives from each customer segment. A business model can generate two types of revenue streams, namely transaction revenues and recurring revenue. There are 2 types of pricing mechanisms, namely fixed price and dynamic pricing.

\section{f) Key Resources}

According to [6], the building blocks of key resources describe the most important company assets needed for a business model to work.

\section{g) Main Activities (Key Activites)}

The building blocks for key activites describe the main activities a company undertakes to make its business model work well. Like major resources, key activities are needed to create value, reach markets, maintain customer relationships, and receive revenue. Key activites can vary depending on the type of business model. Key activites can be divided into production, problem solving and platform / network. 


\section{h) Key Partnerships}

Key partnerships describe the network of suppliers and partners that make the business model work. Companies engage in partnerships for various purposes, and partnerships have become the foundation for many business models. Companies create alliances to optimize their business models, reduce risk, and acquire resources. Partnerships can be divided into several types, namely strategic alliances between non-competing companies, strategic partnerships between competing companies, joint ventures to develop new business, buyer-supplier relationships to ensure guaranteed supply materials.

\section{i) Cost structure (cost structure)}

The cost structure describes all the costs incurred to run the business model. In general, business models have two types of cost structures, namely cost-driven and value-driven.

\section{Research Methods}

This study is qualitative research with a case study method in the marketer village of Tunjungmuli, Purbalingga. The technique of determining informants uses a purposive sampling method, namely determining informants based on the researchers' subjective considerations [7]. The informants were selected based on some criteria: residents should be native from Tunjungmuli and surrounding areas who work in online businesses. All Tunjungmuli residents who work in online businesses were selected as the population of this study, while some of the residents were selected as the samples or informants.

\subsection{Data types and sources}

The type of data used is primary data obtained by interviewing and distributing online questionnaires to informants.

\subsection{Method of collecting data}

The data were collected using in-depth interview techniques with the public relation of the marketer village and employees via WhatsApp. They worked from home in the corona pandemic era.

The stages in the study follow the steps as follows:

a) Pre-Field

1) Drafting the design

2) Choosing and utilizing informants

3) Preparing the instrument

b) Field

1) Understanding and entering the field

2) Collecting the data

\subsection{Data Processing}


Data in the field were outlined in a detailed and complete description or report. The field report will be reduced, summarized, selected for the main things, focused on the essential matters, and then sought patterns and themes.

\subsection{Narration of Analysis Results}

The discussion in qualitative research presents information in the form of written texts. In the narrative, researchers use the canvas business model (MBC).

\section{Results And Discussions}

\subsection{General Description}

a) The Profile of Purbalingga Marketer Village

Purbalingga Marketer Village is an education, training, and empowerment program for villagers to reduce unemployment and urbanization by utilizing IT to produce skilled human resources in internet marketing and online business [9]. Purbalingga Marketer Village with its vision of "Building villages through young people working through technology." Purbalingga Marketer Village actualizes its vision with two primary missions. The first mission of the marketer village is the best place for the education of the village youth to hone their knowledge and skills in e-commerce. The second mission of the marketer villages is the best partner of businessmen in Indonesia to grow more internally by encouraging the youth who are competent in the e-commerce field to collaborate to build a reliable team [8].

The more number of human resources empowered in Marketer Village means the more available knowledge. With the increasing number of partners collaborating, it is also expected that the knowledge possessed by HR will increase. There are several places for empowering HR in Marketer Village. Each place of empowerment has its person in charge. Based on the latest data on empowerment places or workplaces for empowered employees, there are already $20 \mathrm{KM}$ [9].

The place of empowerment or office is spread in 3 districts, namely Karangmoncol Subdistrict, Kertanegara Sub-district, and Rembang Sub-district Purbalingga district, Central Java province. In these offices, employees are empowered to work, starting from 8:00 to 16:30. The latest data has been more than 720 villagers employed with various skills or expertise to work, such as customer service, advertisers, social media admin, content writer, based on demand. Armed with the expertise, they collaborate with online business partners throughout Indonesia [9].

In addition to customer service, the marketer village also provides advertiser staff. Advertisers are advertisers on the internet. They use internet technology to advertise goods/services to all internet users in the world. Advertisers can advertise their products on leading online advertising agencies such as Facebook, Google. The more popular a website (often visited online), the more expensive advertising fees advertisers must pay to website owners (publishers). That is because the website traffic is very high, so the possibility of online clicking on ads will be higher. In other words, advertiser products will have a higher chance of being seen online.

Marketer Village also provides social media admin staff. The task of a Social Media Admin is to manage social media accounts in terms of content. Employees who work in this field have tasks such as designing exciting content, determining the schedule of aired content, and answering all questions/comments/complaints that come from followers. 
Marketer Village also provides Content Writer. Content writer is a professional writer who writes web content or articles to be published on the internet. To maintain business continuity is necessary to set some qualifications before hiring a content writer.

\section{b) Marketed Products}

Purbalingga Marketer Village has collaborated with more than 270 business people from various industry segments from various regions in Indonesia. Marketed products vary from fashion, skincare, educational products, property, drugs, franchises, services, and other products produced by industries and SMEs in collaboration with Marketer Village [8].

\subsection{Identification of the Elements of Business Model Canvas}

This section will present the results of identifying nine elements of the business model canvas in the marketer village.

\subsubsection{Customer segments}

Currently, customer segments from the marketer village are included in the niche market category. From age factor, product buyers in the marketer villages are 13 years old / teenagers up to 50 years.

\subsubsection{Value Proposition}

\section{a) Performance}

Marketer Village provides customer service personnel, advertisers. Marketer Village guarantees that its employees work professionally. The young workers are supposed to have very energetic, friendly, and productive attitudes. Customer service performance is measured by the number of items sold per day.

\section{b) Customization (something interesting and having selling point)}

Marketer Village products are labor service providers that include customer service, advertisers, social media admins, content writers, based on demand, education tours, and training activities/seminars.

Marketer village does advertising on the internet, and social media Facebook, WA, and Instagram of Marketer Village to introduce its advertiser services, customer service, and the community, primarily the target market and clients/producers. Whereas to introduce their products to the public, the main target markets and clients/producers advertise through customer service. The purpose of advertising is that the products offered can be responded to well by the market through product purchase transactions.

\section{c) Design}

Marketer Village has websites such as Instagram accounts and other social media, so they can get to know the wider community. A management team manages the website of Marketer Village.

\section{d) Risk Reduction}

If customer service does not reach a particular sale, the customer service does not get a bonus. The risk that can be faced by the marketer village is the existence of a similar marketer village

\section{e) Accessibility}


Information on the marketer village's products can be obtained on the website and social media. Easy access to information on this website does not require people to enter the marketer village, except to look for details that are not published.

For physical access to the marketer village location, it can be reached by motorized vehicles or cars. The office's position is easily found because it is on the edge of the village's main road. For internet speed, the signal is quite stable to support the marketer village's crew's work. However, not all providers are present in the marketer village area.

\subsection{Channel/distribution}

Clients from the marketer village are 288 companies. The company uses labor from the marketer village to market its products to consumers. The workforce taken is customer service. The number of workers in marketer village is 700 people. Direct distribution is secure. Distribution is done online. Distribution of goods from the client is direct to the buyer, without involving the marketer village. Product buyers can directly buy products to their respective customer service.

\subsection{Customer Relationships}

Good relations with the surrounding community With Marketer Village, it will bring a good impact on the community. Marketer Village has an empowerment program for the elderly, called "makaryo" or working village, which produces ablution slippers. In educational tours, there are activities to distribute groceries to underprivileged communities; Marketer Village also holds educational programs for orphans.

Good relations with producers/partners/clients are done by maintaining the professionalism of its employees. Improvement of employee professionalism is carried out by conducting regular training.

\subsection{Revenue Streams}

The product pricing is done directly by the marketer village/client partner. Customer service only sells goods from the client. The customer service salary comes from the client based on the product sold. Salary and bonus are given to the Customer service.

\subsection{Payment method}

Buyers make transactions directly to the Marketer Village partners. The Marketer Village is only as of the customer service provider.

\subsection{Key Resources}

\subsubsection{Physical resources}

There are 20 offices of Marketer Village spread across three sub-districts in Tunjungmuli, Kretek, Sawangan, Rejawa, and Tamansari. Marketer village as a place to work for customer service is easily reached by motorcycle or car. The location is also easy to reach. The location of the office of Marketer Village is close to where the employees live. Another term of the Marketer Village is a place of empowerment. The number of computers/laptops in marketer village is adequate. The computer/laptop is given by the client/partner, except for the management team's computer. 
Other physical resources, namely the existence of educational tourism facilities in the form of rural nature tourism that can be used for out bonds.

\subsubsection{Human resources}

Marketer Village employs 800 village youth who have been trained in internet marketing to have excellent IT skills. Training is conducted every month. Generally, village youth work as customer service.

\subsubsection{Intellectual resources}

a. KM brand has been patented

b. Employees with Good IT knowledge

c. Highly committed and a large number of partnerships (270)

\subsubsection{Key Activities}

Basically, the products of Marketer Village are labor service providers which include customer service, educational tours and training / seminar activities.

\subsubsection{Key Partnership}

This is about having a business partner who is a prospect in business. In addition, there are also professional IT service providers

\subsubsection{Cost structure}

The costs incurred are the costs of renting shop houses used for the marketer village office, electricity, internet, administration fees and PDAM/ water bills.

Tabel 2. SWOT Analysis Of The Canvas Business Model

\begin{tabular}{|c|c|c|c|c|c|}
\hline No & Aspects & Strengths & Weaknesses & Changes & Threats \\
\hline 1 & $\begin{array}{l}\text { Customer } \\
\text { segments }\end{array}$ & $\begin{array}{l}\text { Various ages } \\
\text { segments can use the } \\
\text { services of marketer } \\
\text { villages }\end{array}$ & $\begin{array}{l}\text { Never focus on } \\
\text { specific } \\
\text { segments }\end{array}$ & $\begin{array}{l}\text { Consumers } \\
\text { from various } \\
\text { background } \\
\text { segments can } \\
\text { use KM }\end{array}$ & $\begin{array}{l}\text { Consumers } \\
\text { move to } \\
\text { other } \\
\text { companies }\end{array}$ \\
\hline \multirow[t]{2}{*}{2} & $\begin{array}{l}\text { Value } \\
\text { Proposition }\end{array}$ & $\begin{array}{l}\text { HR performs } \\
\text { professionally }\end{array}$ & $\begin{array}{l}\text { KM Staff in } \\
\text { Average are } \\
\text { graduated from } \\
\text { High School }\end{array}$ & $\begin{array}{l}\text { The } \\
\text { improvement } \\
\text { of employee } \\
\text { education }\end{array}$ & $\begin{array}{l}\text { Similar } \\
\text { professions } \\
\text { with higher } \\
\text { education } \\
\text { levels }\end{array}$ \\
\hline & & & $\begin{array}{ll}\text { Rooms } & \text { for } \\
\text { training } & \text { are } \\
\text { insufficient } & \end{array}$ & $\begin{array}{l}\text { Additional } \\
\text { training room }\end{array}$ & \\
\hline 3 & $\begin{array}{l}\text { Channel/distrib } \\
\text { ution }\end{array}$ & $\begin{array}{l}\text { Numerous clients } \\
\text { Technology } \\
\text { advances } \\
\text { information }\end{array}$ & - & $\begin{array}{l}\text { Maintaining } \\
\text { the level of } \\
\text { KM } \\
\text { confidence in } \\
\text { clients }\end{array}$ & $\begin{array}{l}\text { There is a } \\
\text { transfer of } \\
\text { the client to } \\
\text { another } \\
\text { place }\end{array}$ \\
\hline
\end{tabular}




\begin{tabular}{|c|c|c|c|c|c|}
\hline & & $\begin{array}{ll}\text { Strong } & \text { direct } \\
\text { distribution } & \end{array}$ & & & $\begin{array}{l}\text { There is a } \\
\text { movement } \\
\text { of } \\
\text { consumers } \\
\text { to other } \\
\text { products }\end{array}$ \\
\hline 4 & $\begin{array}{l}\text { Customer } \\
\text { Relationships }\end{array}$ & $\begin{array}{l}\text { Having a } \\
\text { community } \\
\text { empowerment } \\
\text { program around } \mathrm{KM}\end{array}$ & - & $\begin{array}{l}\text { Improving } \\
\text { similar } \\
\text { programs }\end{array}$ & $\begin{array}{l}\text { There is a } \\
\text { transfer of } \\
\text { the client to } \\
\text { another } \\
\text { place }\end{array}$ \\
\hline 5 & $\begin{array}{l}\text { Revenue } \\
\text { Streams }\end{array}$ & $\begin{array}{l}\text { Income comes from } \\
\text { fees of clients who } \\
\text { use the services of } \\
\text { KM graduates }\end{array}$ & $\begin{array}{lr}\text { KM revenue } \\
\text { depends on the } \\
\text { number } \\
\text { clients }\end{array}$ & Add clients & $\begin{array}{l}\text { Reduced } \\
\text { number of } \\
\text { clients } \\
\text { resign }\end{array}$ \\
\hline 6 & Key Resources & $\begin{array}{l}\text { Human Resources } \\
\text { (HR) } \\
\text { 1. experienced HR } \\
\text { 2. HR are } \\
\text { competent on IT } \\
\text { Physical resources } \\
\text { Numerous office } \\
\text { with affordable } \\
\text { rental fees } \\
\text { Intellectual } \\
\text { Resources } \\
\text { a. KM brand } \\
\text { b. Knowledge } \\
\text { c. Partnership }\end{array}$ & $\begin{array}{l}\text { In Average, they } \\
\text { are graduated } \\
\text { from high } \\
\text { school }\end{array}$ & $\begin{array}{l}\text { Having high } \\
\text { competitivene } \\
\text { ss so that it can } \\
\text { grow bigger }\end{array}$ & $\begin{array}{l}\text { The } \\
\text { emergence } \\
\text { of } \\
\text { competitors } \\
\text { offering the } \\
\text { same } \\
\text { services }\end{array}$ \\
\hline 7 & Key Activities & $\begin{array}{l}\text { customer service, } \\
\text { educational tours } \\
\text { and training / } \\
\text { seminar activities. }\end{array}$ & $\begin{array}{l}\text { CS KM } \\
\text { employees have } \\
\text { a personal } \\
\text { problem that can } \\
\text { interfere with } \\
\text { CS business } \\
\text { communication }\end{array}$ & $\begin{array}{l}\text { Adding other } \\
\text { programs } \\
\text { according to } \\
\text { market } \\
\text { demand and } \\
\text { the latest } \\
\text { technology }\end{array}$ & $\begin{array}{l}\text { The } \\
\text { emergence } \\
\text { of similar } \\
\mathrm{KM} \\
\text { If there is a } \\
\text { robot } \\
\text { application } \\
\text { for CS, KM } \\
\text { has not } \\
\text { anticipated } \\
\text { it }\end{array}$ \\
\hline 8 & Key Partnership & $\begin{array}{l}\text { Having a } \\
\text { professional IT } \\
\text { service provider } \\
\text { business partner }\end{array}$ & $\begin{array}{l}\text { The number of } \\
\text { clients is still } \\
\text { limited in the } \\
\text { regional area }\end{array}$ & $\begin{array}{l}\text { Adding } \\
\text { business } \\
\text { partners to IT } \\
\text { providers }\end{array}$ & $\begin{array}{l}\text { The } \\
\text { emergence } \\
\text { of new, } \\
\text { more } \\
\text { modern } \\
\text { competing } \\
\text { companies }\end{array}$ \\
\hline 9 & Cost Structure & $\begin{array}{l}\text { The cost structure is } \\
\text { more competitive }\end{array}$ & $\begin{array}{l}\text { There are no } \\
\text { security fees }\end{array}$ & $\begin{array}{l}\text { Having the } \\
\text { opportunity to } \\
\text { grow } \\
\text { Efficiently }\end{array}$ & $\begin{array}{l}\text { Computer } \\
\text { theft }\end{array}$ \\
\hline
\end{tabular}


Tabel 3. The existing Business Model Canvas of Marketer VIllage

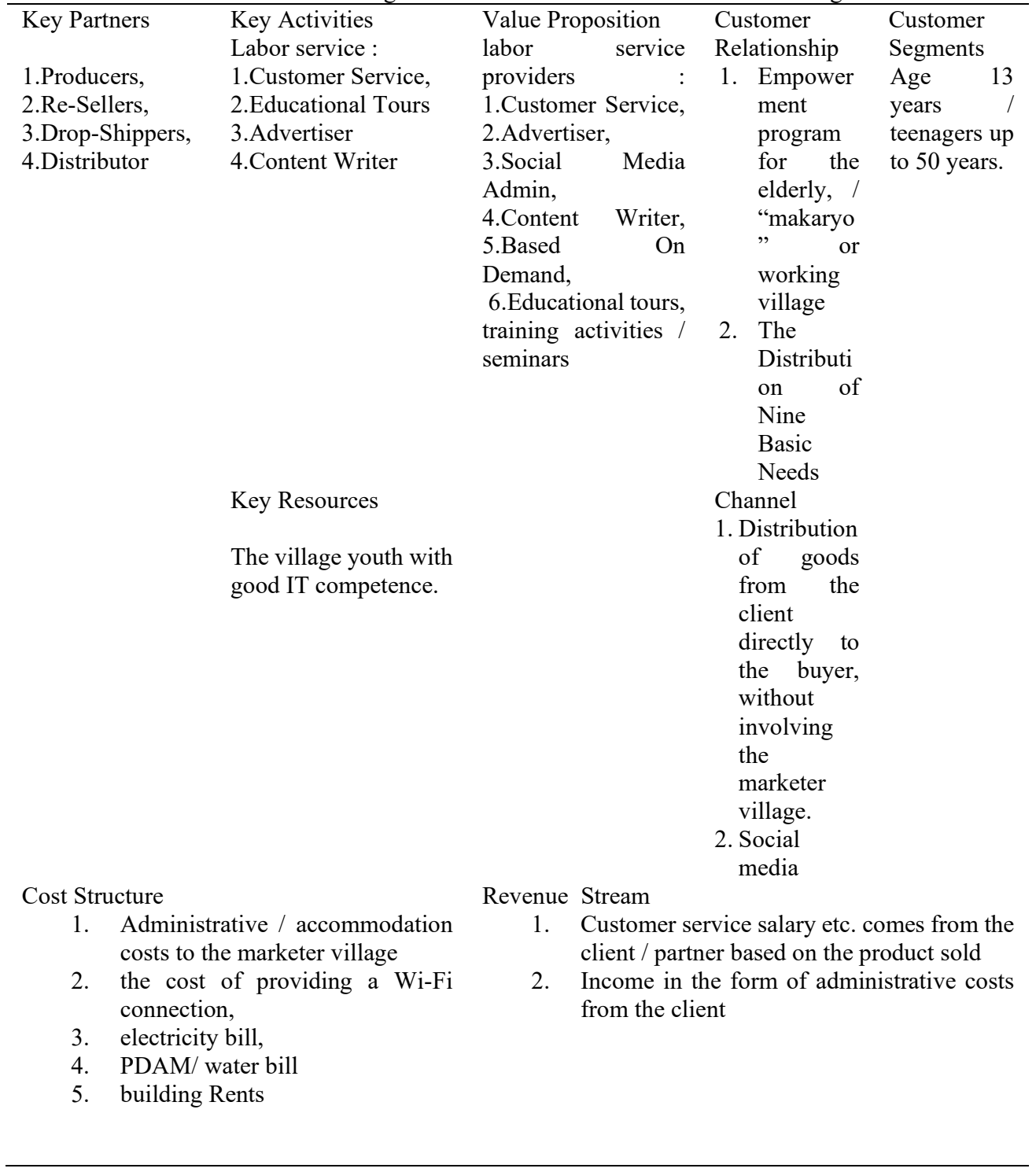


Tabel 4. New Business Model of Canvas Marketer Village

\begin{tabular}{|c|c|c|c|c|}
\hline \multirow[t]{2}{*}{ Key Partners } & Key Activities & Value Proposition & Customer & Customer \\
\hline & $\begin{array}{l}\text { labor service: } \\
\text { 1.customer }\end{array}$ & $\begin{array}{lr}\text { labor } & \text { service } \\
\text { providers } & \text { : }\end{array}$ & $\begin{array}{l}\text { Relationship } \\
1 .\end{array}$ & $\begin{array}{l}\text { Segments } \\
\text { Age } 13 \text { years / }\end{array}$ \\
\hline \multirow{16}{*}{$\begin{array}{l}\text { 1.producers, } \\
\text { 2.re-sellers, } \\
\text { 3.drop-shipper, } \\
\text { 4.distributor } \\
\text { 5.Provider } \\
\text { 6.Schools }\end{array}$} & service, & 1.customer service, & Empowerment & teenager up to \\
\hline & 2.Edu tours & 2.advertiser, & program for the & 50 years. \\
\hline & 3.advertiser & 3.social & elderly, / “ & \\
\hline & 4. content writer & admin, & makaryo" or & \\
\hline & 5.host webinar & 4.content writer, & working village & \\
\hline & & 5.based on demand, & 2. Distribution & \\
\hline & & $\begin{array}{l}\text { 6.education tours } \\
\text { training/seminar }\end{array}$ & of Nine Basic & \\
\hline & & $\begin{array}{l}\text { 7.webinar speaker } \\
\text { related to the society } \\
\text { empowerment }\end{array}$ & & \\
\hline & Key Resources & & Channel & \\
\hline & The Village youth & & 1.Distribution of & \\
\hline & with IT & & goods from the & \\
\hline & competence & & client directly to & \\
\hline & The Improvement & & without & \\
\hline & of Human & & involving & \\
\hline & Resources from & & marketer & \\
\hline & other villages & & village. & \\
\hline \multirow{4}{*}{\multicolumn{2}{|c|}{$\begin{array}{l}\text { Cost Structure } \\
1 \text { marketer administration cost/ } \\
\text { accommodation cost to marketer } \\
\text { village. }\end{array}$}} & \multirow{5}{*}{\multicolumn{3}{|c|}{$\begin{array}{l}\text { Revenue Stream } \\
\text { 1. customer salary service etc from clients/partners based on } \\
\text { the sold products } \\
\text { 2. Revenue such as administration fee from clients. } \\
\text { 3. Revenue such as training fee from education tours }\end{array}$}} \\
\hline & & & & \\
\hline & & & & \\
\hline & & & & \\
\hline \multicolumn{2}{|c|}{ 2.Wi-Fi connection fe } & & & \\
\hline \multicolumn{5}{|c|}{ 3. electricity bill } \\
\hline \multicolumn{5}{|c|}{ 4. PDAM/ water bill } \\
\hline \multicolumn{5}{|l|}{ 5. building rent } \\
\hline 6. security cosy & & & & \\
\hline
\end{tabular}

Based on the table 3, the researcher gave the key partners the item the need for cooperation with the provider because marketers' village activities were more dominant in using the internet, so they needed a strong signal. This cooperation is important to facilitate transaction activities and business communication via the internet in the marketer's village.Partners with schools are also needed to support internet marketing education for students. The marketer's village has held free internet training on Saturdays, but there is no collaboration with the school to attract more training participants. In key activities, in the era of the pandemic, researchers suggested that they host webinars. This activity has been running but has not yet been sold to the public. This is necessary so that the marketer's village is increasingly known to the public. In key resources, researchers suggest increasing the number of staff from outside the village so that the strength of human resources is better and faster in serving customers. In the value proposition, there needs to be a webinar speaker from the marketer's village related to community empowerment, because so far for webinars, there are still speakers from non-village marketers. In the cost structure, there is a need for security costs because there have been several thefts of computer 
assets. In the revenue stream, researchers suggest that there is revenue in the form of training fees from educational tours. This can be done by providing training costs for residents who come from outside the marketer's village area.

\section{Conclusion}

Based on the results and discussion in this study it can be concluded that the mapping of business models with the Business Model Canvas approach is carried out on the nine block elements in it including customer segments, value propositions, channels, customer relationships, revenue streams, key activities, key resources, key partnerships, and the cost structure is broadly said to be good enough. The existing Business models are able to fulfill the nine building block elements of the Business Model Canvas. From the evaluation results using SWOT analysis to the nine-building block elements in the Business Model Canvas regarding the strengths and weaknesses, opportunities, and threats that Marketer Village has, it has resulted in a strategy as the recommendation for Marketer Village management to improve existing business models.

Of the nine-building block elements in the existing Business Model Canvas, researchers recommend additions aimed at nine building blocks, namely Value Propositions, Revenue Streams, Key Resources, Key Activities, Key Partnerships, and Cost Structure.

\section{References}

[1] Adystiana dan Yashinta Model bisnis E-commerce Produk Pertanian (Studi kasus pada PT. Limakilo Maju Bersama petani) Perancangan Model Bisnis Ayam Kashibu Menggunakan Model Bisnis Kanvas

[2] Alvino et al Design Of The Business Model Ayam Kashibu Using Business Model Canvas Journal of Applied Managerial Accounting Vol. 2, No. 1, March 2018, Page 6-14ISSN: 2548-9917 (online version)

[3] Chandra A dan Kempa S Formulasi Business Model Canvas Pada Sifu Pudding Creamjakarta, AGORA Vol. 4, No. 1, (2016)

[4] Munir, D. "SMART VILLAGE: Desa Maju, Desa Bahagia." APEKSI: Asosiasi Pemerintah Kota Seluruh Indonesia, (2017).

[5] Osterwalder, Alexander dan Yves Pigneur. (2012). Business Model Generation. Jakarta: PT. Elexmedia Komputindo. (2012)

[6] Sugiyono, Statistik Untuk Penelitian, (2003)

[7] Ramesh, B. "Concept of Smart Village and it's Impact on Rurbanization." International Journal of Trend in Scientific Reseach and Development 2, no. 3 (2018): 1948-1950

[8] Wahyudi, Hendro Setyo, and Mita Puspita Sukmasari. "Teknologi dan Kehidupan Masyarakat." Jurnal Analisa Sosiologi 3, no. 1 (2018).

[9] Yusuf, Intje. "Analisis Penggunaan Teknologi Informasi (Internet) Terhadap Masyarakat Di Kecamatan Sigi Biromaru Kabupaten Sigi." Katalogis 4, no. 9 : 125-136. Zid, M., Hardi, O. (2016)

[10] https://kampungmarketer.com acces on January 2020

[11] Archive SK-318 / KM / 2019 